7) J.T. Brown, Energy Technol, 13, 1526 (1986).

p. 40 .

8) D.C. Fee ほか 17 名. Abst. 1986 Fuel Cell Seminar,

9) W.J.Dollard and J.T. Brown, ibid., p. 28.

\title{
2 ナトリウム一硫黄電池用固体電解質
}

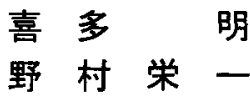

ナトリウムー硫黄電池は，負極にナトリウム，正極に 硫黄（厳密にいえば多硫化ナトリウム）を用いた電池 で, 1967 年に Ford 社の Kummer ら"によってベータ アルミナがナトリウムイオン導電性の固体電解質である ことの発見とともに提唱された電池で，今年が生まれて からちょうど 20 年目ということになる。

この電池は, ベータアルミナを使っていることから ベータ電池ともいわれたり，またベータアルミナがセラ ミックスであることからセラミック電池ともいわれたり する.これらの呼び名はアルカリ電解液を用いている電 池を通常アルカリ電池之呼んでいることと似ている.

この電池の電解質に用いられているべータアルミナ も，この 20 年間に研究が進んで，現在では，化学組成

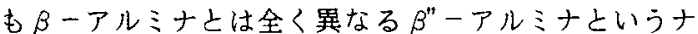
トリウムイオン導電率のより高いセラミックに変わって いる．また，最近ではジルコニアを添加した強靶でこわ れないベータアルミナの研究も進んでおり, ベータアル ミナ固体電解質を用いたナトリウム一硫黄電池が世に出 て社念の役にたつ日も近いと言えるだろう。

ここでは，ナトリウムー硫黄電池を開発している側か らみたベータアルミナを中心よした固体電解筫について ながめてみることにした。

なお，ナトリウム一硫黄電池ではベータアルミナとい

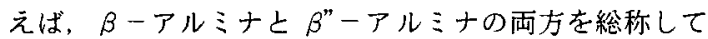
いう場合が多く，また現実のベータアルミナ固体電解質

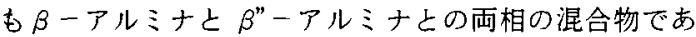
る場合が多い，したがって本稿では $\beta$-アルミナと $\beta ”$ 一アルミナ上の特定が必要でない場合には, ベータアル ミナという呼びかたをすることにした。

\section{1 ナトリウム一硫黄電池の原理と電池構造}

ナトリウムー硫黄電池の原理は，図1に示すように， 負極活物質に溶融金属ナトリウム，正極活物質に溶融硫 黄と多硫化ナトリウムを使用し，電解質にはナトリウム イオン導電性を有するベータアルミナを用いたものであ る.

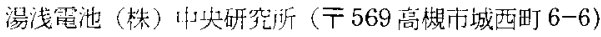

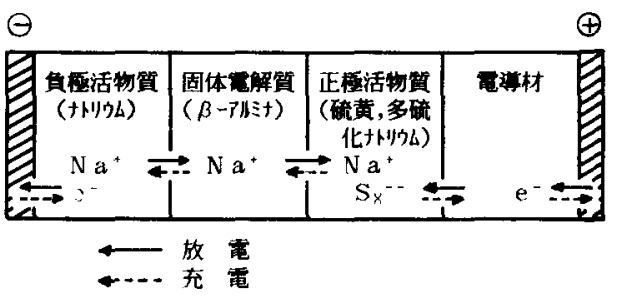

図 1 ナトリウムー硫黄電池の作動原理

起電反応は

負極側 $\quad 2 \mathrm{Na} \underset{\text { 光 }}{\stackrel{\text { 放 }}{\rightleftharpoons}} 2 \mathrm{Na}^{+}+2 \mathrm{e}^{-}$

$$
\text { 正極側 } \mathrm{S}+2 \mathrm{e}^{-} \underset{\text { 故 }}{\rightleftharpoons} \mathrm{S}^{2-}
$$

で, 電池全体としては

$$
2 \mathrm{Na}+\mathrm{S} \underset{\text { 充 }}{\stackrel{\text { 放 }}{\rightleftharpoons}} \mathrm{Na}_{2} \mathrm{~S}
$$

であるが，実際には放電時に正極に生成する反応生成物 の溶䗰温度との関係から

$$
2 \mathrm{Na}+\mathrm{XSS} \underset{\text { 充 }}{\stackrel{\text { 故 }}{\rightleftharpoons}} \mathrm{Na}_{2} \mathrm{Sx}
$$

となる，通常作動させる $623 \mathrm{~K}\left(350^{\circ} \mathrm{C}\right)$ ではXの值は2.7 位の值となる。

電池の構造例を図 2 に示す.図でみられるように,ベー タアルミナ固体電解質は一端が閉じた管状のものを使用 し，その開口部には電気絶縁と電池の完全密封のために

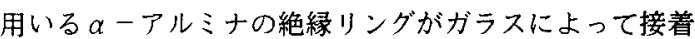
されている，溶融ナトリウムはベータアルミナ管の内側 に，溶融硫黄上多硫化ナトリウムは管の外側に配直され る．正極金属ケースと責極金属端子よは， $\alpha$-アルミナ 絶綅リングを含して接合されている。

ナトリウムー硫黄電池の固体電解質上して求められる 性能としては

1 ・ナリウムイオン導電率が高いこと

2 溶融金属ナトリウムおよび溶融多硫化ナトリウム に対して化学的に安定であること

3 ち密な焼結体であること 


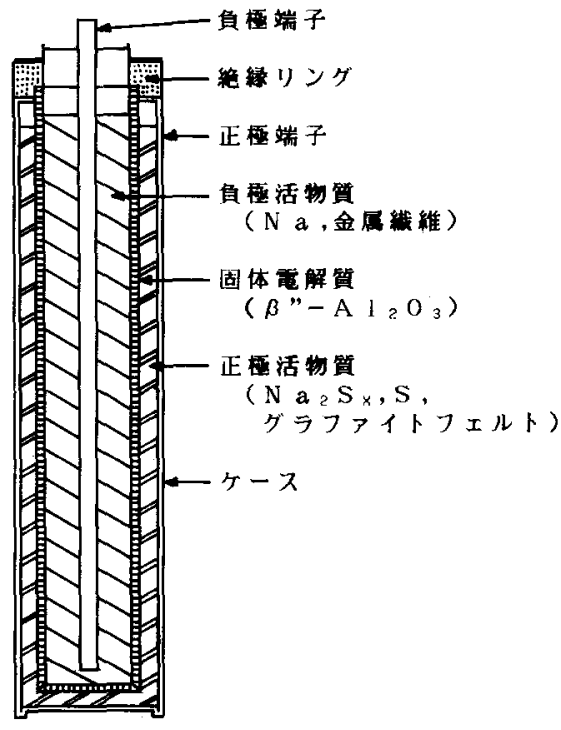

図 2 電池構造

4 機械的強度があること, とくに応力拡大係数が高 いこと

5 管の寸法精度が高いこと。 などがあげられる。

\section{2 ベータアルミナ固体電解質}

ベータアルミナは当初アルミナ $\left(\mathrm{Al}_{2} \mathrm{O}_{3}\right)$ の変態と考 えられ， $\beta$-アルミナと名づけられたものであるが，そ の後の研究によってアルミナの変態ではなく $\mathrm{Al}_{2} \mathrm{O}_{3}$ と $\mathrm{Na}_{2} \mathrm{O}$ との化合物で, 理想式 $\mathrm{Na}_{2} \mathrm{O} \cdot 11 \mathrm{Al}_{2} \mathrm{O}_{3}$ で表され る化合物であることがわかった，そしてさらに理想式 3

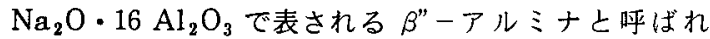
る化合物も存在することもわかった， $\beta$ ーアルミナと $\beta "$ ーアルミナとの間には理想式 $\mathrm{Na}_{2} \mathrm{O} \cdot 7 \mathrm{Al}_{2} \mathrm{O}_{3}$ で表さ れる $\beta^{\prime}$-アルミナも存在していると考えられ, $\beta-, \beta^{\prime}-$, $\beta " 一\left\llcorner\mathrm{Na}_{2} \mathrm{O}\right.$ の量が増えるに従って順番に名付的れ ていったが $\beta^{\prime}$ ーアルミナの存在は否定されて, $\beta$-アル

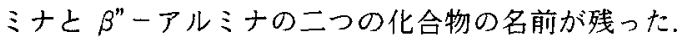

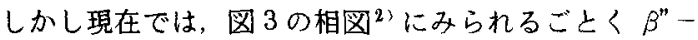
アルミナも $\mathrm{Na}_{2} \mathrm{O}-\mathrm{Al}_{2} \mathrm{O}_{3}$ 二元系には存在しないで, $\beta "$ ーアルミナ相が存在するには第三の添加物が必要である
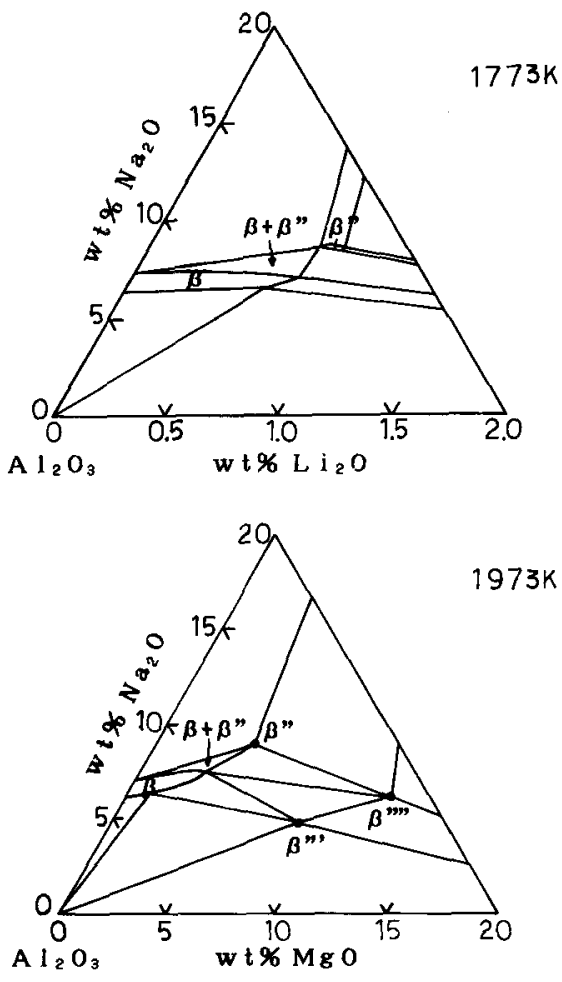

図3ベータアルミナの相図

亡考えられている.

ベータアルミナの結晶構造は $\mathrm{O}^{2-}$ が最密に充塤し (図4の A, B，Cの積み重ねが $\mathrm{O}^{2-}$ の最密パッキング である)、この $\mathrm{O}^{2-}$ の最密パッキングによって生じる八 面体と四面体の間陣に $\mathrm{Al}^{3+}$ がスピネル構造のカチオン と同じように入るスピネルブロックと呼ばれる構造をつ くる. $\mathrm{Na}^{+}$はこのスピネルブロックにはさまれた $\mathrm{O}^{2-}$

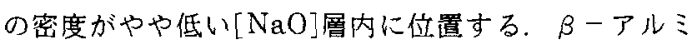
ナはスピネルブロック 2 段で格子単位となり, [NaO]層 がミラ一面となる． $\beta^{\prime \prime ー ア ル ミ ナ は ス ヒ ゚ ネ ル フ ゙ ロ ッ ク ~} 3$ 段で格子単位となる，ナトリウムイオンはこの[NaO] 層にそって移動し，スピネルブロックをつらぬいて移動 することはない.

電池に使われているベータアルミナ管は, 表 1 にま之 めたごとく安定化剂よし $\mathrm{MgO}$ あるいは $\mathrm{Li}_{2} \mathrm{O}$ が添加さ

表 1 実用化されているべータアルミナ管の組成

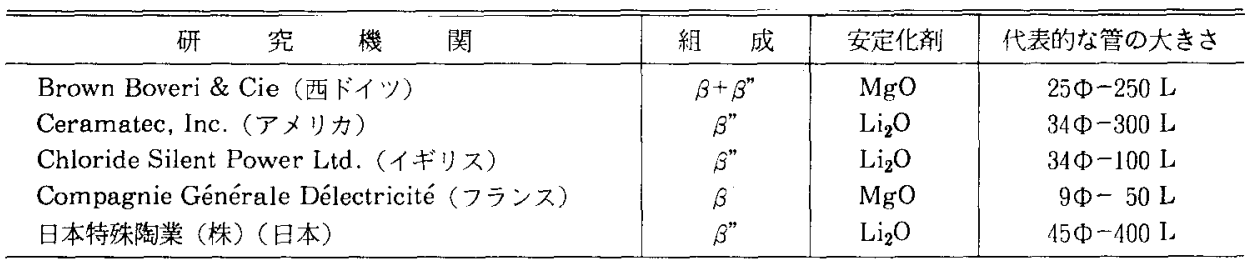


表 2 ベータアルミナ焼結体の物性値

\begin{tabular}{|c|c|c|c|}
\hline & $\beta-ア ル ミ ナ$ & $\beta^{\prime \prime}$ アアルミナ & $\alpha-ア ル ミ ナ$ \\
\hline 密度 $/ \mathrm{gcm}^{-3}$ & 3.20 & 3.24 & 3.99 \\
\hline イオン導電率 $(573 \mathrm{~K}) / \mathrm{Sm}^{-1}$ & 6.5 & $15-30$ & \\
\hline 電子導電率 $(573 \mathrm{~K}) / \mathrm{Sm}^{-1}$ & $10^{-9}$ & & \\
\hline 熱伝導度 $(680 \mathrm{~K}) / \mathrm{Wm}^{-1} \mathrm{~K}^{-1}$ & 2.9 & & $11(773 \mathrm{~K})$ \\
\hline 熱膨張係数 $(300-673 \mathrm{~K}) / \mathrm{K}^{-1}$ & $7.2 \times 10^{-6}$ & $7.8 \times 10^{-6}$ & $7.4 \times 10^{-6}$ \\
\hline 比熱容量 $(373-473 \mathrm{~K}) / \mathrm{Jkg}^{-1} \mathrm{~K}^{-1}$ & $1100(680 \mathrm{~K})$ & & $750-880$ \\
\hline 曲げ強度/MPa & 240 & 235 & 206 \\
\hline 圧環強度/MPa & 190 & 230 & \\
\hline 応力拡大係数 $\mathrm{K}_{\mathrm{IC}} / \mathrm{MNm}^{-3 / 2}$ & 2.7 & 3.0 & 4.1 \\
\hline ヤング乘/GPa & 210 & 196 & 393 \\
\hline 剛性率/GPa & 150 & 142 & 234 \\
\hline ポアソン比 & 0.27 & 0.28 & 0.22 \\
\hline
\end{tabular}
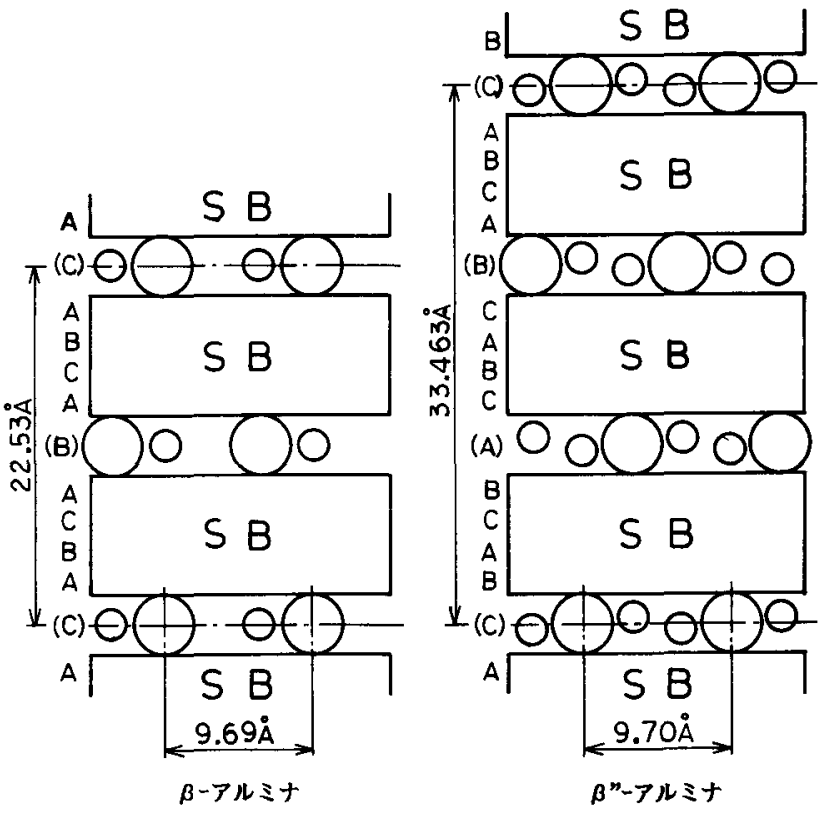

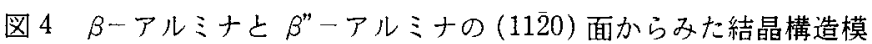
型

$\mathrm{O}$ : 導電層の $\mathrm{O}^{2-}, O: \mathrm{Na}^{+}, \mathrm{SB}:$ スピネルブロック, $\mathrm{A}, \mathrm{B}, \mathrm{C}:$ 最密充てん 層, (A), (B), (C) : 導電傹

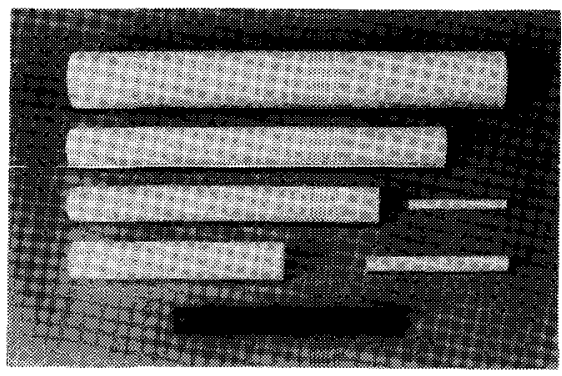

図 5 各種ベータアルミナ管
れた多結晶焼結体である， $\mathrm{Li}_{2} \mathrm{O}$ を添加すると 急－アルミナ相に富んだ焼結体を安定に作りだ すことができ，導電率の高いベータアルミナ管 が得られるため, $\mathrm{MgO} よ り も \mathrm{Li}_{2} \mathrm{O}$ を安定化 剤として利用する場合が多い，図 5 には日本で 試作されているベータアルミナ管を示した，日 本特殊陶業（株）のご好意によるものである.

ベータアルミナ（多結晶焼結体）の物性值を

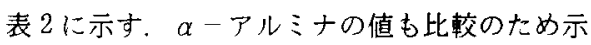
した。焼結体の導電率は， $\beta$ 一相と $\beta$ "一相との 組成比, 焼結密度, 微細結晶構造, 不純物なよ゙ の影響を受けるが，最近のベータアルミナ管の 導電率はこれらがうまく制御されて $30 \mathrm{Sm}^{-1}$ と高くなっている. Wagner 法で測定した電子 導電率は10-9 $\mathrm{Sm}^{-1}$ であり，ほぼないと考え てよい.

機械的性質の一つとして最近は応力拡大係数

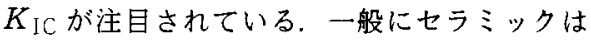
もろくて，壊れやすい性質がある。このもろさ は、一度入った龟裂の伸長の問題であり，以下の 式で表される応力拡大係数 $K_{\mathrm{IC}}$ で評価される.

$$
K_{1 \mathrm{C}}=\sigma \sqrt{\pi a}
$$

ここで $\sigma$ は破壊応力, $a$ は龟裂の長さである. この $K_{\mathrm{IC}}$ は $\mathrm{ZrO}_{2}$ を添加することにより增大するこ とができる. ベータアルミナについても $\mathrm{ZrO}_{2}$ の添加が 試みられており，15 vol\%の $\mathrm{ZrO}_{2}$ を添加すると $K_{\mathrm{IC}}$ が 約 $30 \%$ 増えるという報告がある．ただこの $\mathrm{ZrO}_{2}$ の添 加によってベータアルミナの導電率が低下する上いった 問題があり, 今後の研究課題よなっている.

\section{3 ベータァルミナ以外の固体電解質}

ベータアルミナ以外で, ベータアルミナと同程度の導 電率を有する固体電解質としてはNASICON がある. $\mathrm{Na}_{1+\mathrm{x}} \mathrm{Zr}_{2} \mathrm{P}_{3-\mathrm{x}} \mathrm{Si}_{\mathrm{x}} \mathrm{O}_{12}(0<\mathrm{X}<3)$ という化合物で $\mathrm{NaZr}_{2}$ 
$\left(\mathrm{PO}_{4}\right)_{3}$ と $\mathrm{Na}_{4} \mathrm{Zr}_{2}\left(\mathrm{SiO}_{4}\right)_{3}$ との固溶体である. $573 \mathrm{~K}$ の導電率は $20 \mathrm{Sm}^{-1}$ の值である。この化合物の結晶構 造は $\mathrm{ZrO}_{6}$ のつくる八面体のコーナーのおのおのが $\mathrm{SiO}_{4}$ ，あるいは $\mathrm{PO}_{4}$ の作る四面体のコーナーと共有し あって三次元的につながり，トンネルを造っている。こ の中に $\mathrm{Na}^{+}$が不規則に入って，イオン導電を抏こなう。 NASICON はベータアルミナに代わる固体電解質とし て注目されているが，ナトリウムによって還元されると いう問題があって，ナトリウムー硫黄電池に使われると いうところまでには至っていない,

Dow Chemical 社の進めているナトリウム一硫黄電 池の電解質はホウ酸ガラスを使っている。このホウ酸ガ ラスは $573 \mathrm{~K}$ で $10^{-6} \mathrm{Sm}^{-1}$ の導電率しかないので, 肉 厚を $10 \mu \mathrm{m}$ 位の毛細管にして使っている。このガラス を使った電池はベータアルミナ固体電解質を使った電池 ほどには性能が得られていない。
以上みてきたごよく，ナトリウムー硫黄電池用固体電 解質はベータアルミナ管を中心にして研究が進められて きた。が国では, 現在通産省の大型プロジェクト“ム一 ンライト計画” の中の新型電池電力眝蔵システムの研究 開発が進められており，年間約千本ものベータアルミナ 管が試作されるまでに達している．今後は強度のある ベータアルミ十管を品質良く安定に造れる生産技術の開 発が研究課題であると思われる。 そしてベータアルミナ 固体電解質を使った電池が実用化される日も近いものと 信じている.

\section{文 献}

1) N. Weber and J.T. Kummer, Proc. 21st Annual Power Sources Conf., p. 37 (1967)

2) J.D. Hodge, J. Am. Cer. Soc., 67, 183 (1984).

\section{3ナトリウム熱電変換}

\section{增 田 俊 久 \\ 根 岸明 \\ 田 中 耕太郎}

\section{1 原理と特徵}

熱エネルギーを電気エネルギーに直接変換する方式の 一つとして， $\beta ”$ アルミナ固体電解質を用いたナトリウ 么蒸気圧差熱電変換方式が高効率電源として有望視され ている.

この熱電変換方式は 1968 年 J.T. Kummer $上 N$. Weber により特許とされ, Sodium Heat Engine (SHE) あるいは Alkali Metal Thermo-Electric Converter (AMTEC) 上呼ばれ, Ford Motor 社, Jet Propulsion 研究所および Ceramatec 社などで研究開 発されいる。

図 1 に動作原理を示す1).

高温側では電磁ポンプに上り供給された液体ナトリウ 厶が 600 $1000^{\circ} \mathrm{C}$ に加熱される。この温度におけるナト リウムの蒸気压は $3.03 \times 10^{3} \mathrm{~Pa} 22.63 \times 10^{5} \mathrm{~Pa}$ であ る.このナトリウムは $\beta$ ア アルミナ中を通過し電桖面で 蒸発し，100 500 ${ }^{\circ} \mathrm{C}$ 低温側で液化する.この温度にお けるナトリウムの蒸気圧は $1.01 \times 10^{-4} \mathrm{~Pa} \sim 1.01 \times 10^{3}$ $\mathrm{Pa}$ である. この蒸気圧差により $\mathrm{Na}^{+}$イオンは $\beta ” ア$ ルミナ中を流れ，外部回路が閉じている場合は, $\mathrm{Na}^{+}$

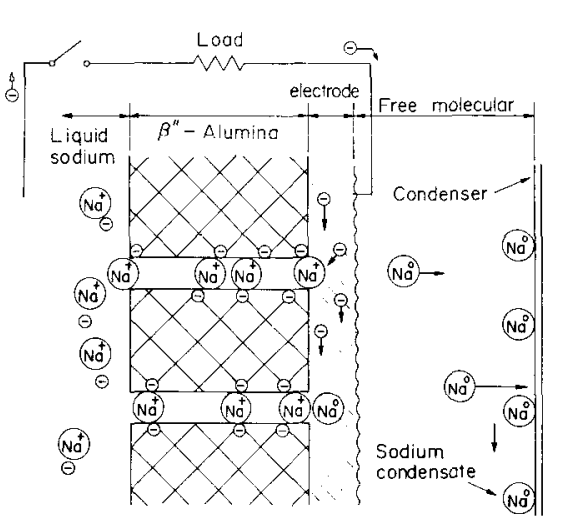

図 1 動作原理図 ${ }^{1}$

イオンは電極面において電子を得て中性化し，低温真空 槽中に蒸発し，電力を発生する．外部回路が開いている 場合は，電極面に電荷が集中し， $\mathrm{Na}^{+}$イオンの流れを 亡める方向に電界が生じ，開放電圧が発生する，低温真 空槽中に蒸発したナトリウム蒸気は真空槽の凝縮面で液 化し，この液体ナトリウムを再び電磁ポンプにより高温 側に連続的に供給することにより発電が持続される。

電極は $\beta "$ アルミナとの界面に電子を供給し $\mathrm{Na}^{+}$イ 